\title{
Kolibri på MR-bilde
}

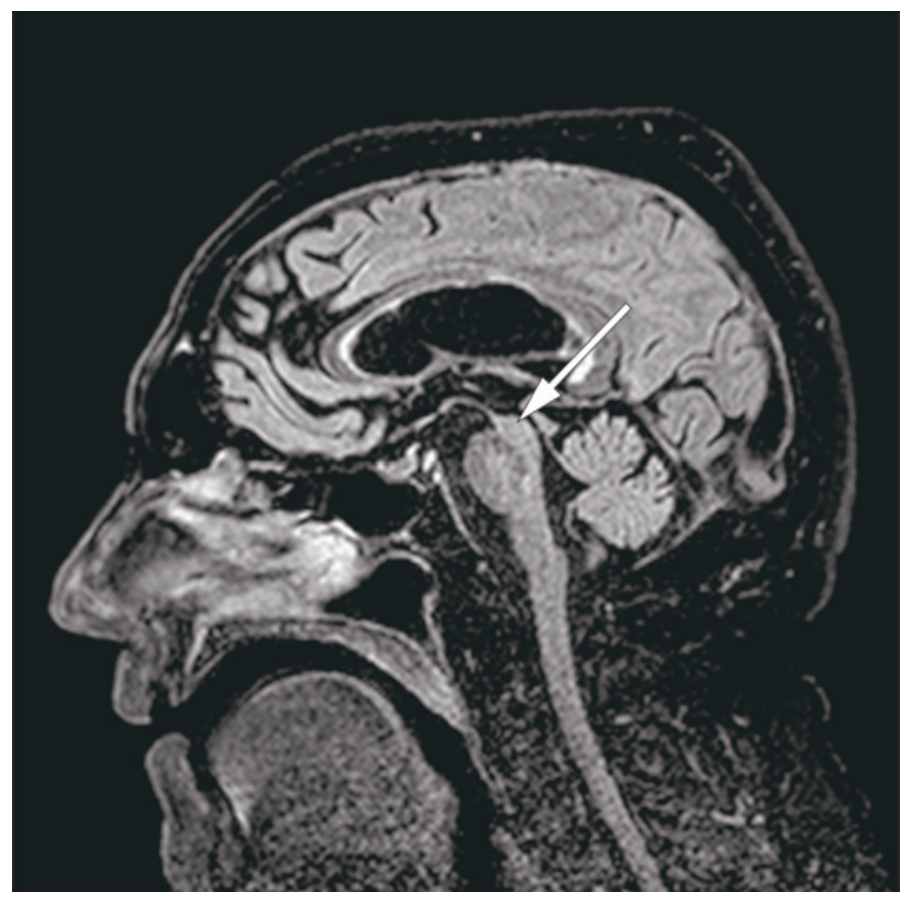

En mann med antatt Parkinsons sykdom ble innlagt i slagavdelingen grunnet økende ustøhet. Foruten parkinsonistiske symptomer hadde han balanseproblemer, kognitiv svekkelse og vertikal blikkparese.

MR-undersøkelse av hjernen viste en uttalt atrofi av mesencephalon som i sagittalsnitt får hjernestammen til å ligne en fugl i profil, gjerne omtalt som kolibritegn eller pingvintegn (pil). Dette er et typisk bildefunn ved den sjeldne nevrodegenerative tilstanden progredierende supranukleær parese (1).

Tilstanden inngår i fellesbetegnelsen atypisk parkinsonisme, en gruppe sjeldne nevrodegenerative tilstander som bør vurderes dersom parkinsonisme opptrer med uvanlige trekk og/eller tilleggssymptomer. Flere av sykdommene har karakteristiske MRfunn som ofte er nøkkelen til at diagnosen stilles (2).

Pasientens pårørende har gitt samtykke til at artikkelen blir publisert.
Vi takker Torgil Vangberg for hjelp med bildebehandlingen.

\section{Christian Borgen Lindstad}

cblindstad@gmail.com

Nyremedisinsk avdeling

Oslo universitetssykehus, Ullevål

\section{Marit Herder}

Radiologisk avdeling

Nevroradiologisk seksjon

Universitetssykehuset Nord-Norge

\section{Claus Albretsen}

Nevrologisk avdeling

Universitetssykehuset Nord-Norge

Christian Borgen Lindstad (f. 1986) er lege i spesialisering $\mathrm{i}$ indremedisin.

Forfatter har fylt ut ICMJE-skjemaet og oppgir ingen interessekonflikter.

Marit Herder (f. 1969) er spesialist i radiologi, overlege og seksjonsleder.

Forfatter har fylt ut ICMJE-skjemaet og oppgir ingen interessekonflikter.
Claus Albretsen (f. 1957) er spesialist i nevrologi, overlege og avdelingsleder. Forfatter har fylt ut ICMJE-skjemaet og oppgir ingen interessekonflikter.

\section{Litteratur \\ 1. Moon WJ, Provenzale JM. Progressive supra- nuclear palsy. I: Osborn AG, Salzman KL, Barko- vich AJ (red.). Diagnostic imaging: brain. 2. utgave. Salt Lake City, UT: Lippincott Williams \& Wilkins/ Amirsys, 2010: 104 \\ 2. Yousem DM, Grossman RI, Zimmerman RD. (red.) Neuroradiology. 3. utgave. Philadelphia, PA: Else- vier, 2010: 256-266}

Mottatt 22.6. 2016, første revisjon innsendt 14.9. 2016, godkjent 25.10. 2016. Redaktør: Inge Rasmus Groote. 